\title{
Ulf, en platonsk dialog
}

\section{Av Vasilis Papageorgiou}

Personer: Ulf och Vasilis.

Scen: Någonstans i Växjö.

Ulf Du menar att det finns tydliga gränser?

Vasilis Man kan på något sätt urskilja något som liknar en sorts avgränsning.

Men det tycker inte du?

Ulf Jag håller med. En sorts avgränsning är inte svårt att beskriva.

Vasilis Skulle du då tycka att det är helt legitimt om jag, när det gäller blues och rock, följer min känsla och väljer fyra utgångspunkter? Fyra musikaliska fält?

Ulf Varför bara fyra?

Vasilis De summerar väl min problematik.

Ulf Och vilka är dessa fyra musikaliska fält?

Vasilis Det är Beatles, Bob Dylan, Eric Clapton och Bryan Ferry.

Ulf Det låter som om du valde dem i alfabetisk ordning.

Vasilis Nej, ingen alfabetisk ordning.

Ulf Följer du en värderande ordning i stället?

Vasilis Ja, ett värderande på något sätt. Men det handlar inte om någon ordning.

Låt mig förklara hur jag föreställer mig deras filosofiska och estetiska inverkan på mig.

Ulf Trots att det i förhållande till dessa namn du här tar upp finns fler musikaliska inriktningar än rock och blues eller andra namn inom rock och blues att diskutera, och trots att det är så tidigt på morgonen, har du väckt min nyfikenhet.

Vasilis Man måste komma hit tidigt på morgonen för att få en chans att träffa dig. Ulf Jag följer hundens tidtabell, vet du. Dessa tidiga promenader i friska luften har gjort att min nyfikenhet är större under morgontimmarna. Det gäller klarsyntheten också. Men berätta nu om dina fyra musikaliska fält.

Vasilis Jag tar Dylan först.

Ulf Vad sa du?

Vasilis Jag förknippar Bob Dylans musik med det som angår själva den mänskliga existensen, som angår människans villkor, som Willy Kyrklund skulle säga.

Ulf Du uppfattar honom som en existentiell musiker?

Vasilis Ja, musiker, lyriker och sångare.

Ulf Jag håller med. Det går inte att skilja det ena från det andra. Men det skulle jag inte påstå om Eric Clapton. Hans röst är inte i paritet med kvaliteten i hans låtar.

Vasilis Jag håller inte med. Men Clapton själv håller med dig. Han avskyr sin egen röst. Ulf Vilken är din uppfattning av honom då? 
Vasilis Dylan står för mig för hela den existentiella problematiken. Han sjunger om människans grundläggande villrådighet och sårbarhet. Den individuella belägenheten har ett direkt allmängiltigt djup. Hos Clapton är detta indirekt. Djupet angår de särskilda mänskliga fall han just då sjunger om men inte hela den mänskliga situationen. Clapton befinner sig inom problematiken. Han problematiserar inte dess helhet. Han problematiserar den inte vidare heller självfallet. Han sjunger om följderna av det som människans villkor orsakar.

Ulf Du menar att Clapton inte är filosofisk?

Vasilis Ja, det menar jag. Inte direkt i alla fall. Han kan underhålla, det kan inte Dylan. Man kan få nog av Dylan men inte av Clapton.

Ulf Som i förhållande mellan Beckett och den tidige Pinter till exempel.

Vasilis Det är suveränt uttryckt.

Ulf Det är suveränt tänkt, skulle Kyrklund säga.

Vasilis Men det är inte fråga om att välja mellan dem. Båda är lika suveräna.

Ulf Inte när det gäller att spela gitarr inte. Elektrisk eller akustisk. Clapton kan inte sjunga men han kan spela gitarr.

Vasilis Jag tycket inte att han problematiserar gitarrspelandet heller. Han fördjupar det på sitt unika och mästerliga sätt men hamnar inte i det bottenlösa.

Ulf Vem av dem du nämnt här gör just detta?

Vasilis Ingen vill jag påstå. Men det bottenlösa finns som en potentiell dimension hos Dylan.

Ulf Skulle du kunna klara dig utan Clapton då?

Vasilis Som jag sa, det är inte fråga om att välja. Skulle du kunna klara dig utan Pinter?

Ulf Så, Dylan står för existensen i sin helhet medan Clapton befinner sig inom existensen. Han kan inte se den i sin helhet eller stå utanför den, som Dylan kan. Vasilis Dylan står aldrig utanför existensen. Det är Bryan Ferry som gör det. Ferry står utanför precis som Clapton står innanför.

Ulf Han har då ingen förståelse för människans villkor?

Vasilis $\AA$, det har han i högsta grad. Men han väljer att stanna vid existensens yta. Han föredrar att stå på utsidan av existensen och polera den ytterligare. Han förvandlar djupet till ytan. Tänk på hur han tolkar Dylans sånger till exempel.

Ulf Hunden vill hem, vet du, och du har inte sagt någonting om Beatles än.

Vasilis Å, Beatles. De står för allt det ovannämnda. Det hela, det innanför och det utanför. Djupet och ytan. De mest tragiska och därför mest komiska av alla. Håller du med? Ulf Jag vet inte. Jag tror inte det. Jag tolkar inte som du. Det låter onödigt ansträngt. Det låter onödigt helt enkelt. Du har säkert vaknat fel i dag. Jag ser det bottenlösa i alla dessa musiker. Det mänskliga har sin egen bottenlöshet och det individuella sin egen. Till och med ytan har sin alldeles egna bottenlöshet. Jag ser den mänskliga tragiken och den mänskliga komiken i alla dina musikaliska fält. Nuförtiden lyssnar jag på jazz från sextitalet. Och jag kan säga dig att det inte är något fusk i denna musik. Man kan fuska med rock men man kan inte fuska med jazz. 